\title{
A NATURE OF THE US AND THE AMERICAN FOREIGN POLICY
}

\author{
Vladislav B. Sotirović* \\ Mykolas Romeris University, Faculty of Politics and Management, \\ Institute of Political Sciences Vilnius, Lithuania
}

The paper deals with the essential nature of the US society and the American foreign policy in a global perspective. The fundamental aim of the paper is to get at the truth about the character of the US global politics as the only world hegemonic power currently, which uses the instrument of the war as the main source for the achievement of its main foreign policy goal: the Pax Americana as the global empire. The main conclusion of the research is that from the very beginning of the existence of the USA in 1776, the warfare is a crucial characteristic of the American culture. This very fact is a direct product and consequence of the nature of the economic system of the US followed by a consumerism mentality of the American society.

Key Words: US, America, war, imperialism, global politics, international relations, Eurasia, foreign policy

"If the Nuremberg Laws were applied, then every post-war American President would have been hanged"

Noam Chomsky

"God created war so that Americans would learn geography"

Mark Twain

\section{Eurasia}

Eenry Kissinger, one of the fundamental figures in creating and maintaining the US policy of global hegemony during the Cold War ${ }^{1}$, was quite clear and precise in his overview of the issue of the American geopolitical position, national goals and foreign policy. His remarks can be summarized in the following points:

\footnotetext{
*Prof. Dr Vladislav B. Sotirović, sotirovic@global-politics.eu

${ }^{1}$ A Jew Henry Kissinger was the National Security Advisor and the Secretary of State during the mandate of the US Presidents Richard Nixon and Gerald Ford. He also advised many other American Presidents on the US foreign policy and global politics. He was one of the most responsible persons for the CIA-organized military putsch in Chile in 1973 and for the US involvement and atrocities committed in Vietnam. Nevertheless, $\mathrm{H}$. Kissinger received the 1973 Nobel Prize and Medal of Liberty, among other awards. He is one of the most notorious symbols of the US gangster-style foreign policy.
} 
A. The US is an island off the shores of the large land mass of Eurasia.

$B$. The resources and population of Eurasia far exceed the resources and population of the US.

C. The domination by any individual state from Eurasia (either from the European or the Asian part) is a critical danger for the American geopolitical and geoeconomic aims, as well as national interest both during and after the time of the Cold War.

D. A mortal danger for the US is the establishment of any political-military coalitions between the Eurasian great powers (primarily between the USSR/Russia and China), as such coalition would have a real capacity to outstrip both the US economy and military.

$\mathrm{E}$. The US strategic global geopolitical interest is to thwart the creation of such Eurasian coalition (the USSR/Russia-China). ${ }^{2}$

In fact, H. Kissinger recognized two fundamental facts in dealing with global geopolitics: 1) Eurasia is of the crucial global geopolitical importance; and 2) Russia is theHeartland of Eurasia. ${ }^{3}$ Therefore, to have the control over Russia means to have the control over Eurasia and to control Eurasia means to control the rest of the world.Therefore, the US struggle against the communist USSR during the Cold War or Putin's Russia today is nothing else than a formal pretext for the performance of the basic US geopolitical task from a global perspective: to have the control over the Heartland of Eurasia. Subsequently, any kind of independent and/or stronger Russia is not acceptable solution for the American policymakers.

\section{A Nature of the US}

In order to properly understand the post-Cold War global hegemonic foreign policy by the US Administration, it is necessary to realize the very nature of the US as a state. Basically, the US foreign policy of global hegemony is shaped by two most important internal processes, which exist from the very beginning of the US independence and statehood (declared in 1776): 1. A mass consumerist mentality of its citizens that is deeply permeated throughout American (sub)culture; 2. Corresponding policy of maintaining the world military supremacy for the sake of ensuring the privileged possession of the global goods, energy, natural resources and credit, for example, there are 800 US military bases across the globe and one of the biggest of them is located in Kosovo (Bondsteel) - one of the richest regions in Europe according to its reserves of the natural resources (at least 500 billion $\$ U S$ ). ${ }^{4}$

The American strategy of global hegemony after the WWII was not only to compete with the Soviet military power and political influence, but it was and still is much more important - to establish the world that is going mandatory to be hospitable for the growth of the US economy. Therefore, the American military-political global dominance has ideologi-

\footnotetext{
2 John Rees, Imperialism and Resistance, London-New York: Routledge, 2006, 18. On this issue, see more in: Henry Kissinger, Diplomacy, New York: Simon \& Schuster Paperbacks, 1994; Henry Kissinger, Does America Need a Foreign Policy? Toward a Diplomacy for the $21^{\text {st }}$ Century, New York: Simon \& Schuster Paperbacks, 2001; Henry Kissinger, World Order, New York: Penguin Books, 2015.

${ }^{3}$ Срђан Перишић, Нова геополитика Русије, Београд: Медија центар „Одбрана“, 2015.

${ }^{4}$ Кавкаски Албанци лажни Илири, Београд: Пешић и синови, 2007.
} 
cally been justified by anti-communism and the US alleged leading role in defending the "free world". However, after the end of the European communism, dissolution of the Warsaw Pact and dismemberment of the USSR, Washington simply justified the continuation of its Cold War policy of global hegemony by defending Europe (and probably the rest of the world) from the "Russian aggression". The "free world" was identified with the full acceptance of the American values, norms, political and economic systems and (sub)culture. According to such geopolitical project, all those governments which rejected to "dance according to the American playing" were proclaimed the enemies of the "free world" and threatened to be bombed and occupied (like the Federal Republic of Yugoslavia in 1999). Nevertheless, the fundamental allegory of the American promotion of independence and democracy (the basic components of the "free world") is that this country is not either really independent (being the West Bank of Israel from 1948 onwards) nor fully democratic (not being even among the first 30 democratic states in the world).

The numerous US military interventions after 1945, as an instrument for the conduct of the geopolitical project of global hegemony, however, have very much undermined the very meaning of democracy, leading at the same time to large-scale human rights abuse. The crucial strategy of the concept of Pax Americana is to maintain cheap supplies of raw materials, especially the cheap supply of oil as the crucial energy source for the US consumerism economy. Therefore, immediately after the WWII, the basic US strategy was to establish the American hegemony in the oil-rich countries in the region of the Middle East, supporting there all kinds of non-democratic and even dictatorial regimes that expressed the political loyalty to Washington such as the regimes of Iran (Persia) from the CIA/M16-sponsored coup in $1953^{5}$ up to the Islamic Revolution in 1978-1979, Kuwait, Bahrein, Qatar and above all Saudi Arabia.

\section{The Middle East and the "Resource War"}

The beginning of the process of making the regional client states started in 1945, when the US President Franklin D. Roosevelt established a strategic partnership with Abdul-Aziz ibn Saud, who was a founder of the modern Saudi royal family and ruling dynasty. The deal was that the US would protect the dynasty, which supported the fundamentalist Wahhabi brand of the Sunni Islam from the beginning, from all inner and outer enemies for the exchange of the US privileged access to the Saudi oil. ${ }^{6}$ Iran was the second country of importance for the US regional "oil policy", where the fundamental American influence was established in 1953, when the CIA-M16 backed the coup against democratically elected PM Mohammad Mossadegh and brought to power in fact the Western oil companies. ${ }^{7}$ Therefore, it is not surprising that the Iranian Revolution was

\footnotetext{
${ }^{5}$ James C. Van Hook (ed.), Foreign Relations of the United States, 1952-1954: Iran, 1951-1954, Washington: United States Government Publishing Office, 2017.

${ }^{6}$ Michael Klare, „Bush-Cheney Energy Strategy: Procuring the Rest of the World's Oil“, Foreign Policy in Focus, 2004: www.fpif.org.

${ }^{7}$ On the CIA's "dirty wars“, see (Douglas Valentine, The CIA as Organized Crime: How Illegal Operations Corrupt America and the World, Atlanta, GA: Clarity Press, INC, 2017).
} 
ideologically and politically an amalgamation of the Islamic Shiite theocracy and very strong anti-Americanism. The US hegemonic design to prevent any hostile actor to gain any foothold in geostrategically and energetically extremely important region of the Middle East was clearly formulated in the 1980 "Carter Doctrine". One of the main reasons for formulating such doctrine was, of course, protection of the existence of the Zionist Israel and its policy of ethnic cleansing of the domestic Palestinians. Therefore, the US policy to project military power into the region of the Middle East became substantially increased followed by abnormal militarization of Israel.

In the years of R. Reagan Administration, the US transformed Afghani Talibans into its sponsored movement and created the long-time partnership with Saudi Arabia and Pakistan in order to maintain Islamist mujahedeen Taliban military capabilities against the Soviet army in Afghanistan, but at the same time to open possibilities for the establishment of different anti-Western jihadist military groups like al-Qaeda of Saudi Osama bin Laden, who would turn back their arms against their sponsors once the Soviet army left Afghanistan. Therefore, the regional militant anti-Western Islamism in different forms that emerged after the Cold War did not arise suddenly out of the framework of the US imperialistic and hegemonic geopolitical ambitions in the Middle East.

A new phase of the US policy in the Middle East came into force in 1990-1991 with the First Gulf War that was fought from the US point of view (like the Second Gulf War in 2003 that resulted in the military occupation of Iraq) for the geopolitical maintenance of the ideology of economic security that was just wrapped into the propaganda of the 2001 G. W. Bush's doctrine of the "War on Terror". In essence, the US Administration fought the First Gulf War for the sake of preventing possible post-Cold War challenges to its hyperpower in global politics in the face of "... the world's effective policeman". G. W. Bush Administration skilfully exploited the atmosphere of fear of the further terrorist attacks in the US society after the terrorist attack of 9/11 that was most probably self-constructed US-Israeli action in which al-Qaeda just played the role of the executor in front of the TV cameras. Subsequently, the most hawkish faces around the US President had the fantastic reason to start the conduct of a long-prepared project of the US world supremacy, unilateral actions and non-limited use of the military capacity of the Pentagon. After the US-led coalition's invasion of Afghanistan in 2001 that was extremely important for having the direct control over the production and distribution of the Afghan heroin at the global market (one road goes via the US colony of Kosovo) and for founding a geostrategic base for the invasion of Iran (the main enemy to Israel after 1979), the invasion of Saddam Hussein's Iraq (fully sponsored by the US Administration of R. Reagan in the war against Iran in the 1980s) became the highest priority of Washington's foreign policy of establishing a global empire. The Pentagon calculated that a new Iraqi colonial regime would transform its country into the US base of military operations in the very centre of the region of the Middle East - the region which is of fundamental geostrategic global importance with huge reserves of oil and natural gas. Therefore, the region would be completely controlled by the US with its military bases in Saudi Arabia, Afghanistan and Iraq followed by strong Israeli and Turkish armies.

\footnotetext{
${ }^{8}$ John Rees, Imperialism and Resistance, London-New York: Routledge, 2006, 17.
} 
Another fact is that the US is still the most oil-dependent economy in the world with the biggest mechanized war machine, which consumes enormous market and therefore Washington's goal was and still is to prevent any global supply disruptions and/or price fluctuations. Due to the fact that the demand for the oil consumption was constantly growing at the world level and that global oil reserves became of extreme importance for the global strategic power in the recent future, after the Cold War the US Administration decided to transform the whole region of the Middle East into its own courtyard for political and economic exploitation. The execution of the plan was going smoothly up to 2014, when Moscow finally decided to crucially defend Syria from the American policy of global banditry, in the same year when the Western Russophobic Drang nach Osten policy was finally stopped in the Euromaidan's Ukraine. From this point of view, the doctrine of "War on Terror" is crucially bound up with the American attempts to establish geostrategic dominance in extremely petrol-rich region of the Middle East for both oil consumption and prevention of the rising power of China to be significantly infiltrated into the region, which has to be reserved mainly for the supply of the US economy. Essentially, the US proclaimed "War on Terror" is nothing else, but profit driven the "Resource War".

\section{Pax Americana and the "Wars of Humanitarian Intervention"}

President B. Obama Administration continued the same G. W. Bush's imperialistic policy of "Resource War" just embracing a more multilateral style of diplomacy and going slowly out of the big ground wars and direct invasions of sovereign states. Nevertheless, he practiced the vigorous use of the American military machinery to attack those who were perceived by the Pentagon to be mostly hostile to the US hegemonic ambitions in the Middle East, and also in the East Africa and the South Asia. The strategy included the expanded use of "kill/capture teams" operated by the US military Joint Special Operations Commandand drone strikes executed both by the CIA and the US army. B. Obama won the Nobel Peace Prize regardless of the very fact that during his presidency there was no a single day of peace. It is calculated that Obama the Bomber dropped during his 8 years of presidency (two terms) a bomb every 20 minutes. For instance, only up to February 2012,

"...the Obama's Administration has carried out at least 239 covert drone strikes, more than five times the 44 approved under George W. Bush. And after promising to make counter-terrorism operations more transparent and rein in executive power, Obama has arguably done the opposite, maintaining secrecy and expanding presidential authority". ${ }^{10}$

The US aggressive, from time to time brutal and inhumane foreign policy of the world militarism and globalization of war for the sake of Pax Americana can be understood only within the full context of the nature of capitalism and the logic of capital itself. ${ }^{11}$ An inte-

\footnotetext{
${ }^{9}$ Michael Chossudovsky, America's "War on Terrorism" in the Wake of 9/11, Second edition, Montréal, Canada: Center for Research on Globalization, 2005.

${ }^{10}$ David Rhode, "The Obama Doctrine: How the President's Drone War is backfiring", Foreign Policy, 201202-27: http://foreignpolicy.com/2012/02/27/the-obama-doctrine/.

${ }^{11}$ On the US globalization of war phenomenon, see in (Michael Chossudovsky, The Globalization of War: America's 'Long War' against Humanity, Montréal, Canada: Center for Research on Globalization, 2015).
} 
gral part of the US foreign policy of global hegemony is the implementation of bilateral agreements with other states to prevent the US soldiers from extradition to the International Criminal Court. In order to force certain countries to conclude such agreement, the US Government threatens them with the withdrawal of its military and other forms of support if they are not willing to sign the agreement. Many states have accepted such deal like Israel, Romania or East-Timor ${ }^{12}$ and therefore legitimised the US Armed Forces to legally violate basic human rights and the rules of war.

On the other hand, the US authority formally uses the military means for interventions for the humanitarian purposes or the protection of human rights. However, that is just a moral excuse for the achievement of the American foreign policy goals, which was clear in many cases, but the most obvious one was in 1999 with the bombing of the Federal Republic of Yugoslavia for the formal sake of protecting Kosovo Albanian human and minority rights. Nevertheless, the prohibition of the use of force by the international law, as it is clearly formulated, for instance, in the UN Charter Article 2, Paragraph 4, is also extended to the so-called „humanitarian intervention" that refers to the unilateral threat or the use of the armed forces by some state against another one to protect the life and liberty of nationals of the latter from acts by their own governments. ${ }^{13}$ However, there is only one possibility, according to the international law, to use the force, including the case of "humanitarian interventions“: it has to be accepted by the UNSC. In other words, only if the UNSC according to the UN Charter Articles 39-42 decides that the human rights violation in some country poses a treat to the international peace and regional security and that the measures of military interventions are necessary, a military intervention against the other state (or its regime) is sanctioned by the international law and community. However, as a matter of fact, the US authority has never received such permission for any of its „humanitarian interventions“, which practically means that the US Government is de facto above the international law and comunity.

The US "Wars of Humanitarian Intervention" in overwhelming majority of cases are based on politically motivated „false flags" produced by the intelligence service (CIA) information backed by the global mainstream media "fake news" at the same time. The Western academic writing even by the most prestigious world universities and publishing houses, unfortunatelly, directly supports such imperialistic wars by giving unproven and false "academic" feedback as it is, for instance, the case with the publication Understanding Global Security by a Senior Lecturer Peter Hough at Middlesex University and published by Routledge. The publication suggests, for instance, that the NATO "humanitarian intervention“ in 1999 against the Federal Republic of Yugoslavia was to „Protect Kosovar Albanians from Serb massacres", ${ }^{14}$ regardless of the fact that the only reason for such NATO aggression was to establish proper political conditions for Kosovo independence from Serbia, transformation of the region into the American political and economic colony and continuation of the historical Albanian ethnic cleansing of the local Serbs and non-Albanians. ${ }^{15}$

\footnotetext{
${ }^{12}$ Peter R. Baehr, Monique Castermans-Holleman, The Role of Human Rights in Foreign Policy, Third edition, New York: Palgrave Macmillan, 2004, 21.

${ }^{13}$ Arie Bloed, Peter van Dijk (eds.), Essays on Human Rights in the Helsinki Process, Dordrecht: Martinus Nijhoff, 1985, 34-35.

${ }^{14}$ Peter Hough, Understanding Global Security, 2nd Edition, London-New York: Routledge, 2008, 127.

${ }^{15}$ Hannes Hofbauer, Eksperiment Kosovo: Povratak kolonijalizma, Beograd: Albatros Plus, 2009.
} 


\section{The Soft Power as a Method}

The use of the Soft Power is another method implied by Washington in dealing with the world politics and international relations. The method refers to the capability of state (or any other actor in global politics) to influence other states, governments or actors to do what the influencer wants, but through persuasion, not force or direct threats. In principle, the Soft Power attracts or co-opts members of government, politicians or citizens by different means including, for instance, bribing, financial donations, offering certain benefits, education, financing political parties, organizing public seminars, etc., but it does not directly force them to do what is required. In this respect, the formal NGOs can play a very important role in the promulgation of the Soft Power method of the American global imperialism like New York-based G. Soros' Open Society Foundation and his Central European University in Budapest. The method covers the wide scope of areas like culture, values, ideas, politics, national identity, history, rights, etc., representing in essence different, but in many cases not smaller forms of influence if compared to the method of the Hard Power, which implies much more direct and essentially coercive measures (like ultimatums, economic santions or threats of the use of the military force). Therefore, the Soft Power method is the other way of achieving the goals by involving persuasion and encouragement usually, but not necessarily, rooted in shared norms, values or/and beliefs.

In general, the method of the Soft Power relies on two instruments:

1. Persuasion - the ability to convince someone by real or false arguments.

2. An ability to attract the people by all possible means.

\section{„Business as Usual“}

The ruling US Neo-Con establishment already started to push the American foreign policy towards the US domination over Eurasia from the second half of the 1990s, which simply meant a geopolitical struggle with Russia. The Kosovo War in 1999 became the first direct challenge to Russian national dignity and geopolitical interests in the region. The architects of the US „Eurasia's imperialism“ understood quite well that the broader Middle East (including the Balkans and the North Africa) was at the heart of the Eurasian problem from different points of view: geopolitical, ideological, economic and strategic. Therefore, both Gulf Wars, the Kosovo War and the Afghan War in between were fought primarily in order to demonstrate the US strong intention to absolutely dominate the Greater Middle East in the post-Cold War era. The Second Gulf War in 2003 was the war of showing to the rest of the world that the US foreign policy of the open banditry is going to be the "business as usual", which had to be silently accepted by the international community. As a matter of fact, it was quite clear that Iraq in 2003 could not develop any kind of effective weapons of mass destruction including some kind of the ABC weapons due to the effective UN economic and other sanctions against S. Hussein's Government. Furthermore, in 1991 Iraq was already so seriously defeated that it could not think for a longer period of time even about just 
revitalizing its regular army, which became weakened even after the Iraq-Iran War in the 1980s. In general, after the First Gulf War in 1991, there was no any serious threat to the US interests in the Persian Gulf region and therefore there was no real reason for the Pentagon to keep up the US presence there.

The US Neo-Con right-wing hawks became influential enough in the Clinton and later the Bush Administration to decide to compel Kissinger's goal of the continuous US domination over the Greater Middle East as in their mind the First Gulf War was the failed war since the American unchallenged dominance over the region was not established. Such foreign policy shift in the Clinton Administration was led by the Secretary of State (a Jew) Madeleine Albright and her mentor a Polish born Zbigniew (Zbig) Brzezinski (not a Jew), who was the US National Security Advisor in the J. Carter Administration and above all an ardent Russophobe. Therefore, the US imperialism started and completed three wars in the area of the Greater Middle East during the Clinton and the Bush Administration from 1999 to 2003: the Kosovo War in 1999, the Afghan War in 2001 and the Second Gulf War in 2003. However, the Arab Spring in 2011 and especially the Russian military intervention in Syria since 2014 onwards have clearly shown that the area of the Middle East is still not an exclusive American colonial domain.

\section{Conclusion}

To conclude, from the very beginning of the existence of the USA in 1776, the warfare was, still is and is probably going to be the nature of the American life and (sub)civilization. ${ }^{16}$ This very fact is a direct product and consequence of the nature of the economic system of the US and a consumerism mentality of its citizens. The effects on the world security and global peace are obvious.

\section{Bibliography}

[1] Arie Bloed, Peter van Dijk (eds.), Essays on Human Rights in the Helsinki Process, Dordrecht: Martinus Nijhoff, 1985.

[2] David Rhode, "The Obama Doctrine: How the President's Drone War is backfiring", Foreign Policy, 2012-02-27: http://foreignpolicy.com/2012/02/27/the-obama-doctrine/.

[3] Douglas Valentine, The CIA as Organized Crime: How Illegal Operations Corrupt America and the World, Atlanta, GA: Clarity Press, INC, 2017. 2009.

[4] Hannes Hofbauer, Eksperiment Kosovo: Povratak kolonijalizma, Beograd: Albatros Plus,

[5] Henry Kissinger, Diplomacy, New York: Simon \& Schuster Paperbacks, 1994.

[6] Henry Kissinger, Does America Need a Foreign Policy? Toward a Diplomacy for the $21^{\text {st }}$ Century, New York: Simon \& Schuster Paperbacks, 2001.

[7] Henry Kissinger, World Order, New York: Penguin Books, 2015.

\footnotetext{
${ }^{16}$ On this issue, see (Paul Atwood, War and Empire: The American Way of Life, London: Pluto Press, 2010).
} 
[8] James C. Van Hook (ed.), Foreign Relations of the United States, 1952-1954: Iran, 1951-1954, Washington: United States Government Publishing Office, 2017.

[9] John Rees, Imperialism and Resistance, London-New York: Routledge, 2006.

[10] Michael Chossudovsky, America's "War on Terrorism" in the Wake of 9/11, Second edition, Montréal, Canada: Center for Research on Globalization, 2005.

[11] Michael Chossudovsky, The Globalization of War: America's 'Long War' against Humanity, Montréal, Canada: Center for Research on Globalization, 2015.

[12] Michael Klare, „Bush-Cheney Energy Strategy: Procuring the Rest of the World's Oil“, Foreign Policy in Focus, 2004: www.fpif.org.

[13] Paul Atwood, War and Empire: The American Way of Life, London: Pluto Press, 2010. 2008.

[14] Peter Hough, Understanding Global Security, 2nd Edition, London-New York: Routledge,

[15] Peter R. Baehr, Monique Castermans-Holleman, The Role of Human Rights in Foreign Policy, Third edition, New York: Palgrave Macmillan, 2004.

[16] Кавкаски Албанци лажни Илири, Београд: Пешић и синови, 2007. 2015.

[17] Срђан Перишић, Нова геополитика Русије, Београд: Медија центар „Одбрана“, 